\title{
Amazonian Fruits: An Overview of Nutrients, Calories and Use in Metabolic Disorders
}

\author{
Moacir Couto de Andrade Júnior ${ }^{1 *}$, Jerusa Souza Andrade ${ }^{1,2}$ \\ ${ }^{1}$ Laboratory of Nutrition, Universidade Nilton Lins, Manaus, Brazil \\ ${ }^{2}$ Department of Food Technology, Instituto Nacional de Pesquisas da Amazônia (INPA), Manaus, Brazil \\ Email: ${ }^{*}$ moacirir@uol.com.br
}

Received 30 June 2014; revised 3 August 2014; accepted 16 August 2014

Copyright $@ 2014$ by authors and Scientific Research Publishing Inc.

This work is licensed under the Creative Commons Attribution International License (CC BY).

http://creativecommons.org/licenses/by/4.0/

(c) (1) Open Access

\begin{abstract}
Amazonian fruits are outstanding in quality. They are consumed as true delicacies of nature by the Brazilian population. Besides their attractive attributes, i.e. appearance, different textures and distinctive flavors, their nutritional value is diversified in the type of calories and the functional food ingredients. In addition to being very palatable, Amazonian fruits provide energy-rich macronutrients (lipids, proteins and carbohydrates), micronutrients (minerals, water-soluble vitamins and fat-soluble vitamins), prebiotics (dietary fibers, especially pectin), bioactive substances (carotenoids and polyphenols), variety in the diet and improvement in the organoleptic properties and digestibility of (mixed) foods. This study first aimed to review concepts applicable to nutritional constituents and caloric contents of Amazonian fruits. It also attempted to clarify the potential use of these fruits in metabolic disorders (i.e. diabetes mellitus and/or obesity). To fulfill these purposes, 12 fruits were chosen for their dietetic significance in the Brazilian Amazonia.
\end{abstract}

\section{Keywords}

Oleaginous Fruits, Starchy-Oily Fruits, Fleshy Fruits, Diabetes Mellitus, Obesity

\section{Introduction}

Humans are omnivorous and the domestication of crops was preceded by animal domestication [1] [2]. With the advent of agriculture, plants have been critical to the wellness of human society and the sustainability of the planet's ecosystem [3]. Domestication of cereals began around 12,000 years ago in the Middle East and spread throughout Europe before it was developed elsewhere [4]. Reference [2] includes an in-depth review of domestication and early culture of fruit crops throughout the world. Two other reviews focus on the origin and domes-

\footnotetext{
"Corresponding author.
} 
tication of native Amazonian crops [5] [6]. As further discussed, some Amazonian fruits are unique in desirable nutritional features. But first, it is imperative to review the importance of fruits (in general) for human nutrition.

Fruits are major ingredients of human diet that provide several nutritional constituents and caloric contents [7] [8]. Metabolizable calories are chiefly derived from lipids (triglycerides, $9 \mathrm{kcal} / \mathrm{g}$ ) proteins and carbohydrates (4 $\mathrm{kcal} / \mathrm{g}$ ) [8] [9]. Proteins and free amino acids are minor constituents of fruits, being primarily functional (e.g. enzymes), rather than acting as a storage pool, as in cereals and nuts [7] [10]. Starch is the main reserve carbohydrate of many higher plants (up to $75 \%$ of the dry mass in cereals) and glucose is the most important energy component for most living organisms [11] [12]. Fruit micronutrients comprise minerals (or ash), water-soluble vitamins (e.g. L-ascorbic acid or vitamin C) and fat-soluble vitamins (e.g. tocopherol or vitamin E). Most importantly, fruits possess essential nutrients such as vitamin $C$ for humans because of their deficiency in L-gulono$\gamma$-lactone oxidase (EC 1.1.3.8), the enzyme catalyzing the terminal step in the vitamin C biosynthesis [13]. In contrast, there is no vitamin B12 in fruits and other vegetal foods because microorganisms constitute the sole source of this micronutrient in nature [14] [15].

Fruits are also rich in constituents that may provide a health benefit beyond basic nutrition (functional food definition) such as the abovementioned vitamins, dietary fibers (or prebiotics), polyphenols (mainly flavonoids) and carotenoids [7] [16]-[25]. Dietary fibers may be defined as the portions of plant foods that are resistant to digestion by human intestinal enzymes [17]. In addition, these nondigestible portions of plant foods may be defined as prebiotics because they beneficially affect the host by selectively stimulating the growth and/or activity of one or a limited number of bacteria in the colon, thus improving host health [18] [19]. Their prebiotic effect primarily depends on their degradation by human gut microbiota. Soluble fibers (e.g. pectin) are highly fermented in the colon [20]. Insoluble fibers (e.g. cellulose, lignin) exert bulking action, but are fermented only to a limited extent in the colon, especially lignin [20] [22].

Besides, plant primary metabolites (e.g. lipids, amino acids, carbohydrates, nucleotides, steroids) are organic compounds that are common to all (or most) plant species and are fundamental for plant growth, development and reproduction [26]. In opposition, plant secondary metabolites are often referred to as organic compounds that play no fundamental role in the maintenance of life processes in the plants, but they are important not only for the plant to interact with its environment (adaptation and defense), but also for the energy capture from the solar emission spectrum [25] [27]. Hence, primary and secondary metabolites are connected by intermediates such as carbohydrates, which exert the most significant effects on flavonoids production and partitioning in plant organs [28]. Other secondary metabolites, such as capsaicinoids, are nonnutrient compounds exclusive to the genus Capsicum (Solanaceae family), produced only in the fruit (placenta) and tightly linked to the defense of the developing embryos [29] [30]. Furthermore, secondary metabolite production (e.g. carotenoids) is controlled during fruit ripening [30] [31]. Ripening changes in carotenoids are apparent in fruit deepened colors and increasing pigment contents [31].

As a final point, water content in fruits represents a very high percentage of fresh mass that must be taken into account in diet formulations (1 ml/kcal) [7] [15] [32] [33].

Many of these attributes are abundant in Amazonian fruits and relevant to human health, drawing the attention of research groups worldwide. This study first aimed to review concepts applicable to nutritional constituents and caloric contents of Amazonian fruits. It also attempted to clarify the potential use of these fruits in metabolic disorders (i.e. diabetes mellitus and/or obesity). To fulfill these purposes, 12 fruits were chosen for their dietetic significance in the Brazilian Amazonia (Table 1).

\section{Nutritional Constituents and Caloric Contents of Amazonian Fruits}

As to Amazonian fruits, they are outstanding in quality. They are consumed as true delicacies of nature by the Brazilian population. Besides their attractive attributes, i.e. appearance (great sizes, various shapes and intense colors), different textures and distinctive flavors, their nutritional value is diversified in the type of calories and the functional food ingredients. Given this diversity, Amazonian fruits can be simultaneously categorized as energy-dense fruits and nutrient-dense fruits. Nevertheless, the concept of energy-dense fruits is self-limited to calories, whereas that of nutrient-dense fruits is broader and comprises other functional food constituents, especially essential amino acids [34]-[37]. Birds, for instance, may cope with protein shortage either by switching to insectivory or by increasing their rate of fruit intake [38]-[40]. Human cultures have found, over time, the proper mixture of amino acids in traditional dishes (cereals and legumes, cereals and dairy products, legumes and seeds), promoting protein balance and healthy weight and height development for their children [31]. 
Table 1. Significant fruits in Amazonian diet.

\begin{tabular}{|c|c|c|}
\hline Botanical Families & Species $^{\mathrm{a}}$ & Common Names $^{\mathrm{b}}$ \\
\hline Bromeliaceae & Ananas comosus (L.) Merr. & Abacaxi (pineapple) \\
\hline Arecaceae & Euterpe oleracea Mart. & Açaí \\
\hline Arecaceae & Mauritia flexuosa L. f. & Buriti \\
\hline Myrtaceae Juss. & Myrciaria dubia (Kunth) McVaugh & Camu-camu \\
\hline Lecythidaceae A. Rich. & Bertholletia excelsa Bonpl. & Castanha-do-pará (Brazil nut) \\
\hline Solanaceae & Solanum sessiliflorum Dunal & Cubiu \\
\hline Malvaceae Juss. & Theobroma grandiflorum (Willd. ex Spreng.) K. Schum. & Cupuaçu \\
\hline Annonaceae & Annona muricata L. & Graviola \\
\hline Arecaceae & Oenocarpus bataua Mart. & Patauá \\
\hline Arecaceae & Bactris gasipaes Kunth & Pupunha (peach palm) \\
\hline Anacardiaceae & Spondias mombin L. & Taperebá \\
\hline Arecaceae & Astrocaryum spp. & Tucumã \\
\hline
\end{tabular}

${ }^{\mathrm{a}}$ For other fruits, scientific names were only cited once; ${ }^{\mathrm{b}}$ For simplicity, only common Brazilian and English names were used.

Energy density of foods may be defined as the energy per unit weight or volume (kcal/100g or megajoules per kilogram) [35]. A joule is the energy expended when $1 \mathrm{~kg}$ is moved $1 \mathrm{~m}$ by a force of 1 Newton, being the accepted standard unit of energy used in human energetics and also recommended for the expression of energy in foods [41]. However, it remains true that both joules (kJ) and calories (kcal) are used side by side in most regulatory frameworks [41]. In this work, energy in fruits was preferentially expressed in $\mathrm{kJ} / 100 \mathrm{~g}$.

According to the predominance of energy-rich macronutrients, Amazonian fruits could be classified as highlipid fruits (oleaginous fruits and nuts) and/or as high-carbohydrate fruits (starchy-oily fruits and fleshy fruits). But this classification does not correspond to the complex composition of these fruits, as discussed below.

Plant triglyceride synthesis in the endoplasmic reticulum may have evolved with specific subcellular machinery, allowing important oil storage in oilseeds or oleaginous fruits [42]. World-famous fruits such as avocado (Persea americana Mill., Lauraceae) and olive (Olea europaea L., Oleaceae) have, respectively, 20\% and 15\% oil present as oil droplets in their cells [43]. On the contrary, an unknown Amazonian oleaginous fruit, patauá, has (g/100g dry matter) 60.19 of edible lipids, (5.62) proteins, (5.54) dietary fibers and (1.84) ash [44]. In the Amazonian region, oleaginous fruits such as patauá, açaí and buriti are similar in the processing, i.e. with softening of the pulp by tepid water immersion first, followed by scraping/pressing of the fruit (release and fragmentation of the pulp), sieving (retention of the seeds and noncrushed fragments) and homogenization of the pulp in a dense juice, then consumed in various culinary preparations [44]. Açaí maceration produces a thick, purple beverage of creamy texture, oily appearance and characteristic flavor [45]. Buriti dense juice is golden yellow, oily, with a unique flavor. The main nutritional constituents and caloric contents of these oleaginous fruits are given in Table 2.

Nuts may be defined as hard-shelled dried fruits or seeds having a more or less distinct separable shell or rind and interior kernel or meat; also the kernel or meat thereof [50]. Fresh castanhas-do-pará (Brazil nuts) may be cited as the example of fruits rich in all caloric sources $(\mathrm{g} / 100 \mathrm{~g})$ and other constituents herein discussed, i.e. lipids (63.5), carbohydrates (15.1), proteins (14.5), dietary fibers (7.9), ash (3.4), moisture (3.5) and energy (2690 kJ/100g) [46] [50]. There is also a net predominance of unsaturated fatty acids over saturated fatty acids [46]. Brazil nuts are the richest source in selenium, a mineral incorporated into selenoproteins that have a wide range of pleiotropic effects, extending from antioxidant and anti-inflammatory effects to the production of active thyroid hormone (or triiodothyronine) [51] [52]. Nevertheless, selenium content in Brazil nuts varies greatly [52].

Amazonian starchy-oily fruits (semantically) differ from oleaginous fruits and nuts since they are equally rich in carbohydrates and lipids but poorer in proteins. Pupunha (peach palm) is the starchy-oily fruit par excellence. It is the only neotropical palm domesticated by Native Americans [5] [6] [53]-[55]. The whole fruits (peel, pulp and seed) are boiled with a little salt and subsequently peeled for prompt consumption (Figure 1). As such their content (g/100g) of carbohydrates consists of 29.6, lipids (12.8), proteins (2.5), dietary fibers (4.3), ash (0.7), moisture (54.5) and energy (914 kJ/100g) [46]. There is also a net predominance of unsaturated fatty acids over saturated fatty acids [46]. Moreover, peach palm may be turned into a sweet-smelling flour. However, the macronutrient contribution to the flour is different according to the peach palm population (Figure 2). Data showed 
Table 2. Composition of significant oleaginous fruits in Amazonian diet.

\begin{tabular}{ccccccccc}
\hline \multirow{2}{*}{ Fruits $^{\mathrm{a}}$} & \multicolumn{9}{c}{ Components (g/100g fresh weight) } & \multicolumn{2}{c}{ References } \\
\cline { 2 - 7 } & Lipids & Carbohydrates & Proteins & Dietary fibers & Ash & Moisture & Energy (kJ) & \\
\hline Açaí (frozen pulp) & 3.9 & 6.2 & 0.8 & 2.6 & 0.3 & 88.7 & 243 & {$[46]$} \\
Buriti & 19.0 & 26.2 & 3.7 & 22.8 & 0.6 & 50.5 & 1006 & {$[47]$} \\
Patauá & 14.4 & 46.1 & 4.9 & 29.7 & 1.1 & 33.5 & 1132 & {$[47]$} \\
\hline
\end{tabular}

aThe composition varies in bioactive substances: Açaí is rich in anthocyanins, buriti in carotenoids and patauá and buriti in tocopherol [44] [47]-[49].

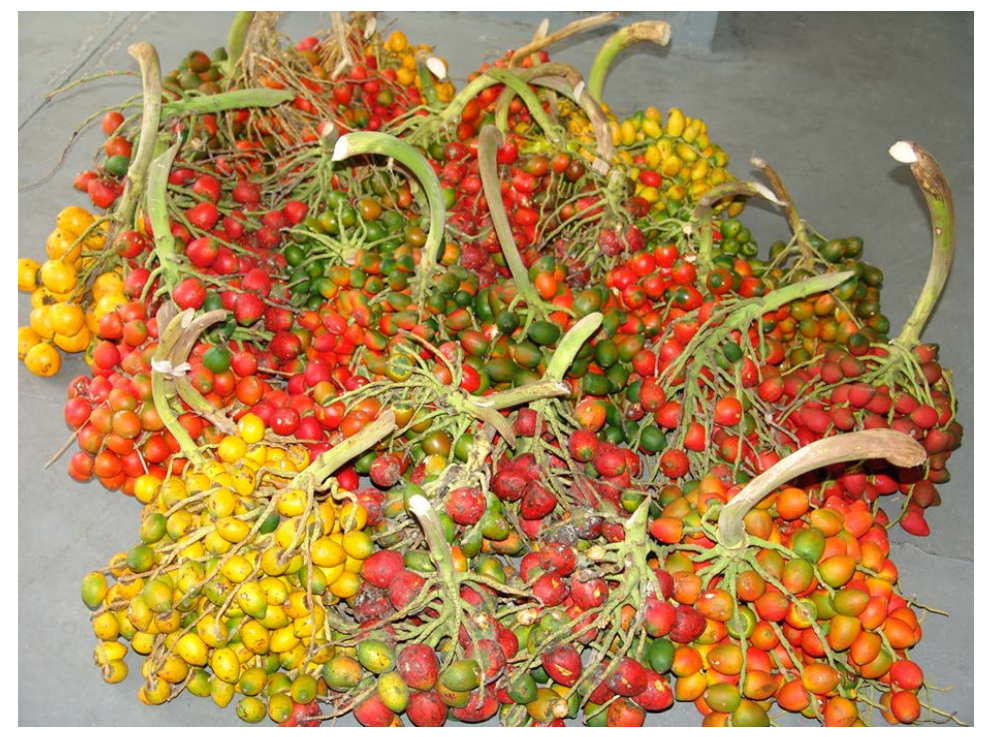

Figure 1. Peach palm fruits at different ripening stages. Fruits at the turning stage (first appearance of yellow color at the blossom end) may already be boiled for consumption, according to Amazonian natives.

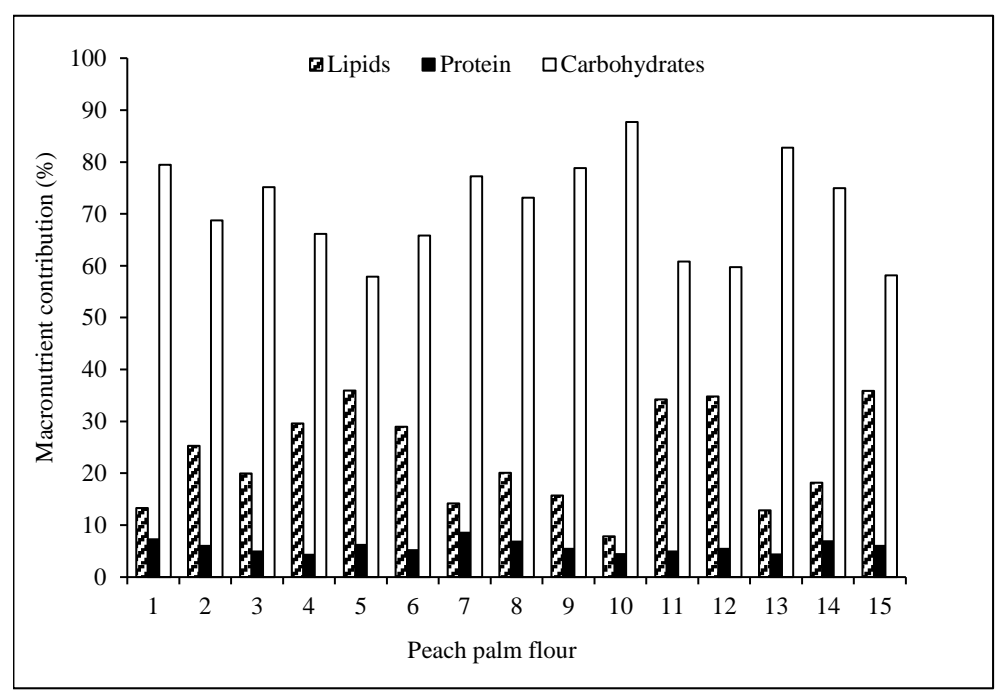

Figure 2. Percentage contribution of macronutrients to the peach palm flour according to 15 different fruit populations (unpublished data).

that the nutritional value of wheat bread, in terms of fiber and total carotenoids, improved significantly with the addition of peach palm flour [56]. Peach palm is a very important nutritional source whose starchy-oily fruits are subsistence products and whose heart-of-palm is an expanding agribusiness [55]. 
Tucumã may be cited as the second most significant Amazonian starchy-oily fruit. Its distinctive flavor and unctuous texture are parts of its hedonic character, explaining why it frequently composes the breakfast in Brazilian Amazonia. Its pulp may be consumed freshly or as an ingredient in numerous food preparations. As such its content (g/100g) of carbohydrates consists of 26.5, lipids (19.1), proteins (2.1), dietary fibers (12.7), ash (1.1), moisture (51.3) and energy (1096 kJ/100g) [46].

Therefore, in relation to energy-rich macronutrients, the conceptual limits (definitions) of terms such as oleaginous fruits, nuts and starchy-oily fruits are very tenuous [57]. In this context, their interchangeable usage is acceptable. Another similarity among them is due to high content of unsaturated fatty acid in buriti, patauá and tucumã [44].

Fleshy fruits are defined as fruits consisting mainly of a soft succulent tissue made of water-rich parenchyma, named pulp (or flesh), including two main types of fruit, drupes and berries [58]. Minerals, vitamins, prebiotics and bioactive substances are abundant in fleshy fruits of the Brazilian Amazonia. These healthy compounds define high-quality fruits and are developed during fruit ripening [59].

Fleshy Amazonian fruits are also designated as succulent fruits. Although, technologically, it is more appropriate to designate citrus fruits as succulent fruits because their compression easily squeezes juice out. In Amazonian fleshy fruits, despite storing a great amount of liquid, juice extraction is much more laborious. Abacaxi (pineapple), camu-camu, cubiu, cupuaçu, graviola and taperebá are high-quality fleshy fruits whose main nutritional constituents and caloric contents are given in Table 3.

Some of these fleshy fruits possess unique characteristics that must be singled out herein. First, pineapple is the leading edible member of the family Bromeliaceae, grown in several tropical and subtropical countries [62]. Pineapple is a large fruit whose preparation requires extensive peeling, slicing and disposal of the rind and core [63]. It is usually eaten raw or as juice or in different fermented beverages and culinary preparations [64]. Its medicinal properties (e.g. fibrinolytic, antithrombotic) derive from bromelain, a generic term for two enzymes extracted from pineapple fruit (EC 3.4.22.33) and pineapple stem (EC 3.4.22.32) [62]. Bromelain is absorbed without losing its proteolytic activity and without producing any major side effects [62]. Second, camu-camu fruits are appropriately considered the richest natural source of vitamin C in Brazil [60]. Vitamin C contents are variable in camu-camu fruits, but they are usually superior to $2 \mathrm{~g} / 100 \mathrm{~g}$ [60] [65]. To close, cubiu fruits are made up by the endocarp (also called placenta), a soft-textured tissue that fills out the whole locular cavity and by the harder-textured surrounding pulp (or mesocarp), with a variable thickness proportional to the size of the fruit [66]. Cubiu fruits are appreciated not only for their high viscosity and acid taste, but also for their content in water and minerals, usually accompanying fish dishes as important dietary supplements in Brazilian Amazonia [31]. Cubiu fruits are particularly rich in soluble fibers (pectin), carotenoids and phenolic compounds [24] [31] [66]. All these fleshy fruits possess high nutrient density, low caloric content and might be usefully manipulated in metabolic disorders, as briefly discussed in the following section.

\section{Potential Use of Amazonian Fruits in Metabolic Disorders}

According to neurobiologists, eating and drinking are major drive states (motivational states) related to survival and foods are the basic survival needs for human beings [67] [68]. Motivational states respond to numerous factors, such as sensory properties of foods (e.g. appearance, texture, flavor) and orexigenic and anorexigenic neuropeptides (both of which are involved in the control of energy homeostasis or balance) [67] [69] [70]. Energy

Table 3. Composition of significant fleshy fruits in Amazonian diet.

\begin{tabular}{cccccccccc}
\hline \multirow{2}{*}{ Fruits } & \multicolumn{9}{c}{ Components (g/100g fresh weight) } \\
\cline { 2 - 8 } & Lipids & Carbohydrates & Proteins & Dietary fibers & Ash & Moisture & Energy (kJ) & References \\
\hline Abacaxi (pineapple) & 0.1 & 12.3 & 0.9 & 1.0 & 0.4 & 86.3 & 202 & {$[46]$} \\
Camu-camu & 0.2 & 1.28 & 0.4 & 0.1 & 0.3 & 94.1 & 36 & {$[60]$} \\
Cubiu & 0.3 & 5.2 & 0.7 & 1.6 & 0.4 & 91.7 & 124 & {$[31]$} \\
Cupuaçu & 1.0 & 10.4 & 1.2 & 3.1 & 1.2 & 86.2 & 207 & {$[46]$} \\
Graviola & 0.2 & 15.8 & 0.8 & 1.9 & 1.0 & 82.2 & 258 & {$[46]$} \\
Taperebá & 2.1 & 14.2 & 1.4 & 1.2 & 0.6 & 88.5 & 125 & {$[61]$} \\
\hline
\end{tabular}


balance is achieved when energy intake equals energy expenditure and is maintained within narrow limits over prolonged periods [71]-[73]. Although humans occupy the top position in the phylogenetic scale, they are not distant from other species concerning the permanent energy needs [74] [75]. However, the shift from huntergatherer to agricultural societies has allowed increasing numbers of humans to obtain food with reduced expenditure of energy, but at the expense of a higher risk of developing obesity dependent diabetes mellitus (or diabesity) [76] [77]. It is generally assumed that a (hypothetical) thrifty genotype, once adjusted to constant human famine, now lends heightened tendency to develop diabesity in certain ethnic groups (e.g. American Pima Indians) exposed to contemporary food abundance [78] [79]. In contrast, lifestyle factors, such as low-fat diet (staple-based diet) and high physical activity (horticulture), would act as protecting factors against metabolic disorders in other ethnic groups (e.g. Ecuadorian Shuar Indians) [80]-[83]. Besides western diet and sedentary lifestyle, environmental contamination, i.e. exposure to xenobiotics (or man-made chemicals) is related to disruption of energy metabolism and insufficient sirtuin family members (SIRT1-7, principally SIRT1) increases xenobiotic half-life and risk for obesity and diabetes with neurodegeneration in developing countries [84]-[91].

Given that no food contains all the nutrients necessary for human health, the perfect diet should be a varied and inclusive diet, especially with regards to fruits. Fruit seasonality should be taught to diabetic patients so that they might take the most advantage of fruit nutritional value. For instance, the chemical composition of patauá varies during the harvest season (from June to December), but the entire season is worthy since this fruit can be collected periodically [44]. As patauá is a high-energy fruit, it would be especially indicated for diabetic patients with malnutrition. Additionally, Brazil nuts might be incorporated into recipes for their richness in all energyrich macronutrients herein discussed. Patients should also learn how to prioritize the consumption of high-carbohydrate fruits during hypoglycemic episodes (glycemia $<70 \mathrm{mg} / \mathrm{dL}$ ). Despite the importance of consuming "empty calories" (e.g. added sugars) to a more rapid return to normal glycemia (70-99 mg/dL), afterwards, it should be switched to the consumption of more complex carbohydrates found in bread enriched with the peach palm fruit flour (separately, peach palm fruit is a low-glycemic index fruit) [46] [56] [92] [93]. The juices of high-carbohydrate fleshy fruits such as graviola, taperebá, pineapple and cupuaçu could also be useful in hypoglycemic episodes [94] [95]. Dietary fibers have been shown to induce satiety [96]. Cubiu fruits are particularly rich in pectin and could be potentially used in the control of diabetes mellitus and obesity [66] [97] [98]. However, animal-experiment data have shown that highly methoxylated pectin is more effective in metabolic disorders than low methoxylated pectin, highlighting the necessity to determine the degree of methoxylation (or esterification) of cubiu pectin and warranting its later evaluation in humans [99]-[101]. Moreover, cubiu and camu-camu are low caloric fruits potentially fit for diabetic patients with obesity.

Nevertheless, there is an important gap between the potential health benefits of Amazonian fruits and their applicability in current clinical practice. Fruit pollutants must be tested and regulated by authorities in order to ensure that the risks are minimal and acceptable in the context of the benefits [69]. Aside from widespread fruits in world markets (e.g. pineapple and Brazil nuts), most Amazonian fruits are subsistence products that are still labeled as unconventional fruits and neglected and underutilized species (NUS), thus not being subjected to well-established toxicity tests [55] [102]-[105]. Although direct fruit peel monitoring of xenobiotics is currently available by exposing it (without any pretreatment) to direct analysis in real time coupled to a high-resolution orbitrap mass spectrometer [106]. On the other hand, nutritional diets (plant versus meat) are designed to maintain the toxicological processing of xenobiotics with the critical role of liver xenobiotic enzymes (cytochrome P450 or CYP450) in their metabolism [87]. Xenobiotics are metabolized first by a phase I system (CYP450) which modifies the compounds so that they have hydrophilic functional groups for increased solubility [107]. The phase II detoxification systems involve conjugation reactions that attach charged hydrophilic molecular moieties to reactive metabolites, thus facilitating the elimination of the harmful metabolites from the body and ultimately reducing their toxicity [107]. Phenolic phytochemicals and carotenoids can activate enzymatic systems (phase II) involved in the detoxification of xenobiotics [108] [109]. Depressed microsomal oxygenation of many xenobiotics is an essential function of vitamin C, in addition to facilitating the elimination of phase I products by UDPGA-mediated conjugation to glucuronides [110]. Diets that contain appropriate protein quality, carbohydrate and lipid (polyunsaturated) content as well as minerals and vitamins (e.g. nicotinamide, riboflavin, niacin, folic acid, vitamin E) are essential for xenobiotic metabolism [87]. All these attributes of nutritional dense foods are present in Amazonian fruits and could potentially diminish the rapid xenobiotic metabolism triggered by low-calorie diets and poor nutrition [87]. Finally, genotoxic stress is defined as the induction (e.g. by xenobiotics) of DNA damage and the response of the cell to that damage [87] [111]. The in vivo antimuta- 
genic effects found in açaí pulp, buriti oil and cubiu pulp encourage further studies [112] [113]. Tucumã extracts would present in vitro genotoxic effects that are dependent on concentration and time exposition, needing consideration in future research [114].

\section{Conclusion}

It is promising to study the composition and the functionality of Amazonian fruits. This task is even more facilitated by their exceptional sensory properties. The sweet smell of peach palm flour fills the laboratory of nutrition in the afternoons, foreshadowing days of healthier foods for human populations. The multicentric study of these fruits also shed light on many aspects related to their postharvest physiology and biochemistry. Most of all, multidisciplinary cooperation is crucial for the understanding of complex plant organs such as fruits. However, as pointed out above, there are still many questions to be addressed before a (functional) fruit could replace a (prompt) medicine, especially in the field of metabolic disorders. The 12 fruits herein reviewed are significant in the Amazonian diet, being characterized as energy-dense fruits (açaí, Brazil nuts, buriti, tucumã, patauá and peach palm) and nutrient-dense, low-calorie fruits (camu-camu, cubiu, cupuaçu, graviola, pineapple and taperebá).

\section{Acknowledgements}

The authors are grateful to the financial support provided by Coordenação de Aperfeiçoamento de Pessoal de Nível Superior (CAPES), Conselho Nacional de Desenvolvimento Científico e Tecnológico (CNPq) and Fundação de Amparo à Pesquisa do Estado do Amazonas (FAPEAM).

\section{References}

[1] Pereira, P.M. and Vicente, A.F. (2013) Meat Nutritional Composition and Nutritive Role in the Human Diet. Meat Science, 9, 586-592. http://dx.doi.org/10.1016/j.meatsci.2012.09.018

[2] Janick, J. (2005) The Origins of Fruits, Fruit Growing, and Fruit Breeding. Plant Breeding Reviews, 25, $255-321$. http://dx.doi.org/10.1002/9780470650301

[3] Bozhkov, P.V. and Lam, E. (2011) Green Death: Revealing Programmed Cell Death in Plants. Cell Death and Differentiation, 18, 1239-1240. http://dx.doi.org/10.1038/cdd.2011.86

[4] Brand-Miller, J.C., Griffin, H.J. and Colagiuri, S. (2012) The Carnivore Connection Hypothesis: Revisited. Journal of Obesity, 2012, 6 p. http://dx.doi.org/10.1155/2012/258624

[5] Clement, C.R., De Cristo-Araújo, M., Coppens D’Eeckenbrugge, G., Alves Pereira, A. and Picanço-Rodrigues, D. (2010) Origin and Domestication of Native Amazonian Crops. Diversity, 2, 72-106. http://dx.doi.org/10.3390/d2010072

[6] Clement, C.R. (1999) 1492 and the Loss of Amazonian Crop Genetic Resources. I. The Relation between Domestication and Human Population Decline. Economic Botany, 53, 188-202. http://dx.doi.org/10.1007/BF02866498

[7] Paliyath, G., Tiwari, K., Sitbon, C. and Whitaker, B.D. (2012) Biochemistry of Fruits. In: Simpson, B.K., Nollet, L.M.L., Toldrá, F., Benjakul, S., Paliyath, G. and Hui, Y.H., Eds., Food Biochemistry and Food Processing, 2nd Edition, John Wiley \& Sons, Inc., Hoboken, 531-553. http://dx.doi.org/10.1002/9781118308035

[8] Ristow, M. and Zarse, K. (2010) How Increased Oxidative Stress Promotes Longevity and Metabolic Health: The Concept of Mitochondrial Hormesis (Mitohormesis). Experimental Gerontology, 45, 410-418. http://dx.doi.org/10.1016/j.exger.2010.03.014

[9] Moldoveanu, S.C. (2012) Profiling of Lipids from Fruit and Seed Extracts. In: Chen, S., Ed., Lipidomics: Sea Food, Marine Based Dietary Supplement, Fruit and Seed, Transworld Research Network, Kerala, 73-123.

[10] Abu-Goukh, A.B.A., Shattir, A.E.T. and Mahdi, E.F.M. (2010) Physico-Chemical Changes during Growth and Development of Papaya Fruit. II: Chemical Changes. Agriculture and Biology Journal of North America, 1, 871-877.

[11] Lima, D.M., Fernandes, P., Sampaio Nascimento, D., Figueiredo Ribeiro, R. De C.L. and De Assis, S.A. (2011) Fructose Syrup: A Biotechnology Asset. Food Technology \& Biotechnology, 49, 424-434.

[12] Ishibashi, Y., Kohyama-Koganeya, A. and Hirabayashi, Y. (2013) New Insights on Glucosylated Lipids: Metabolism and Functions. Biochimica et Biophysica Acta, 1831, 1475-1485. http://dx.doi.org/10.1016/j.bbalip.2013.06.001

[13] Nishikimi, M., Fukuyama, R., Minoshima, S., Shimizu, N. and Yagi, K. (1994) Cloning and Chromosomal Mapping of the Human Nonfunctional Gene for L-Gulono-Gamma-Lactone Oxidase, the Enzyme for L-Ascorbic Acid Biosynthesis Missing in Man. The Journal of Biological Chemistry, 269, 13685-13688. 
[14] Butensky, E., Harmatz, P. and Lubin, B. (2008) Nutritional Anemias. In: Duggan, C., Watkins, J.B. and Walker, W.A., Eds., Nutrition in Pediatrics: Basic Science, Clinical Applications, PMPH-USA, Hamilton, 701-711.

[15] Morgan, S.L. and Weinsier, R.L. (1998) Fundamentals of Clinical Nutrition. 2nd Edition, Mosby, St. Louis, 271 p.

[16] Das, A., Raychaudhuri, U. and Chakraborty, R. (2012) Cereal Based Functional Food of Indian Subcontinent: A Review. Journal of Food Science and Technology, 49, 665-672. http://dx.doi.org/10.1007/s13197-011-0474-1

[17] Anderson, J.W., Baird, P., Davis Jr., R.H., Ferreri, S., Knudtson, M., Koraym, A., Waters, V. and Williams, C.L. (2009) Health Benefits of Dietary Fiber. Nutrition Reviews, 67, 188-205. http://dx.doi.org/10.1111/j.1753-4887.2009.00189.x

[18] Gibson, G.R. and Roberfroid, M.B. (1995) Dietary Modulation of the Human Colonic Microbiota: Introducing the Concept of Prebiotics. Journal of Nutrition, 125, 1401-1412.

[19] Shukla, S., Shukla, A., Mehboob, S. and Guha, S. (2011) Meta-Analysis: The Effects of Gut Flora Modulation Using Prebiotics, Probiotics and Synbiotics on Minimal Hepatic Encephalopathy. Alimentary Pharmacology and Therapeutics, 33, 662-671. http://dx.doi.org/10.1111/j.1365-2036.2010.04574.x

[20] Dandona, P., Ghanim, H., Chaudhuri, A., Dhindsa, S. and Kim, S.S. (2010) Macronutrient Intake Induces Oxidative and Inflammatory Stress: Potential Relevance to Atherosclerosis and Insulin Resistance. Experimental \& Molecular Medicine, 42, 245-253. http://dx.doi.org/10.3858/emm.2010.42.4.033

[21] Raman, M., Ambalam, P., Kondepudi, K.K., Pithva, S., Kothari, C., Patel, A.T., Purama, R.K., Dave, J.M. and Vyas, B.R.M. (2013) Potential of Probiotics, Prebiotics and Synbiotics for Management of Colorectal Cancer. Gut Microbes, 4, 181-192. http://dx.doi.org/10.4161/gmic.23919

[22] Aura, A.M., Niemi, P., Mattila, I., Niemelä, K., Smeds, A., Tamminen, T., Faulds, C., Buchert, J. and Poutanen, K. (2013) Release of Small Phenolic Compounds from Brewer's Spent Grain and Its Lignin Fractions by Human Intestinal Microbiota in Vitro. Journal of Agricultural and Food Chemistry, 61, 9744-9753. http://dx.doi.org/10.1021/jf4024195

[23] Bao, H., Ren, H., Endo, H., Takagi, Y. and Hayashi, T. (2004) Effects of Heating and the Addition of Seasonings on the Anti-Mutagenic and Anti-Oxidative Activities of Polyphenols. Food Chemistry, 86, 517-524. http://dx.doi.org/10.1016/j.foodchem.2003.09.004

[24] Rodrigues, E., Mariutti, L.R.B. and Mercadante, A.Z. (2013) Carotenoids and Phenolic Compounds from Solanum sessiliflorum, an Unexploited Amazonian Fruit, and Their Scavenging Capacities against Reactive Oxygen and Nitrogen Species. Journal of Agricultural and Food Chemistry, 61, 3022-3029. http://dx.doi.org/10.1021/jf3054214

[25] Ramakrishna, A. and Ravishankar, G.A. (2011) Influence of Abiotic Stress Signals on Secondary Metabolites in Plants. Plant Signaling \& Behavior, 6, 1720-1731. http://dx.doi.org/10.4161/psb.6.11.17613

[26] Deborde, C. and Jacob, D. (2014) MeRy-B, a Metabolomic Database and Knowledge Base for Exploring Plant Primary Metabolism. In: Sriram, G., Ed., Plant Metabolism: Methods and Protocols, Methods in Molecular Biology, Springer Science + Business Media, New York, 3-16. http://dx.doi.org/10.1007/978-1-62703-661-0_1

[27] Cazzonelli, C.I. (2011) Carotenoids in Nature: Insights from Plants and Beyond. Functional Plant Biology, 38, 833847. http://dx.doi.org/10.1071/FP11192

[28] Ghasemzadeh, A. and Jaafar, H.Z.E. (2011) Effect of $\mathrm{CO}_{2}$ Enrichment on Synthesis of Some Primary and Secondary Metabolites in Ginger (Zingiber officinale Roscoe). International Journal of Molecular Sciences, 12, 1101-1114. http://dx.doi.org/10.3390/ijms12021101

[29] Naresh, P., Reddy, K.M., Reddy, M.K. and Ravishankar, K.V. (2012) Variability in Capsaicinoids Content and Phylogenetic Analysis of AT3, an Acyltransferase Gene in Chilli (Capsicum annuum L.). Vegetable Science, 39, 16-20.

[30] Levey, D.J., Tewksbury, J.J., Izhaki, I., Tsahar, E. and Haak, D.C. (2007) Evolutionary Ecology of Secondary Compounds in Ripe Fruit: Case Studies with Capsaicin and Emodin. In: Dennis, A.J., Schupp, E.W., Green, R.J. and Westcott, D.A., Eds., Seed Dispersal: Theory and Its Application in a Changing World, CAB International, Oxfordshire, 37-58. http://dx.doi.org/10.1079/9781845931650.0037

[31] Andrade Jr., M.C. and Andrade, J.S. (2012) Physicochemical Changes in Cubiu Fruits (Solanum sessiliflorum Dunal) at Different Ripening Stages. Food Science and Technology, 32, 250-254. http://dx.doi.org/10.1590/S0101-20612012005000049

[32] Lemmens, F. (2011) Sports Nutrition in Children and Adolescents: Scientific Base and Practical Aspects. Journal du Pédiatre Belge, 13, 42-46.

[33] Bresson, J.L. and Goudable, J. (2013) Child Hydration and Dipsic Behavior (Hydratation de l'Enfant et Comportement Dipsique). Cahiers de Nutrition et de Diététique, 48, 41-52. http://dx.doi.org/10.1016/j.cnd.2012.10.006

[34] Darmon, N., Briend, A. and Drewnowski, A. (2004) Energy-Dense Diets Are Associated with Lower Diet Costs: A Community Study of French Adults. Public Health Nutrition, 7, 21-27. http://dx.doi.org/10.1079/PHN2003512

[35] Drewnowski, A. and Darmon, N. (2005) The Economics of Obesity: Dietary Energy Density and Energy Cost. The American Journal of Clinical Nutrition, 82, 265S-273S. 
[36] Newmark, H.L. (1987) Nutrient Density: An Important and Useful Tool for Laboratory Animal Studies. Carcinogenesis, 8, 871-873. http://dx.doi.org/10.1093/carcin/8.7.871

[37] Drewnowski, A. and Fulgoni III, V. (2008) Nutrient Profiling of Foods: Creating a Nutrient-Rich Food Index. Nutrition Reviews, 66, 23-39. http://dx.doi.org/10.1111/j.1753-4887.2007.00003.x

[38] Izhaki, I. (1992) A Comparative Analysis of the Nutritional Quality of Mixed and Exclusive Fruit Diets for YellowVented Bulbuls. The Condor, 94, 912-923. http://dx.doi.org/10.2307/1369288

[39] Izhaki, I. (1993) Influence of Nonprotein Nitrogen on Estimation of Protein from Total Nitrogen in Fleshy Fruits. Journal of Chemical Ecology, 19, 2605-2615. http://dx.doi.org/10.1007/BF00980695

[40] Izhaki, I. (1998) Essential Amino Acid Composition of Fleshy Fruits versus Maintenance Requirements of Passerine Birds. Journal of Chemical Ecology, 24, 1333-1345. http://dx.doi.org/10.1023/A:1021274716062

[41] Food and Agriculture Organization of the United Nations-FAO (2003) Food Energy-Methods of Analysis and Conversion Factors. FAO Food and Nutrition Paper, 77, 1-87.

[42] Chapmana, K.D., Dyerb, J.M. and Mullenc, R.T. (2013) Commentary: Why Don't Plant Leaves Get Fat? Plant Science, 207, 128-134. http://dx.doi.org/10.1016/j.plantsci.2013.03.003

[43] Wills, R.B.H., Lee, T.H., Graham, D., McGlasson, W.B. and Hall, E.G. (1982) Postharvest: An Introduction to the Physiology and Handling of Fruit and Vegetables. 2nd Edition, UNSW Press Ltd., New South Wales, 161 p.

[44] Souza, R.S., Andrade, J.S. and Costa, S.S. (2012) Effect of the Harvest Date on the Chemical Composition of Patauá (Oenocarpus bataua Mart.) Fruits from a Forest Reserve in the Brazilian Amazon. International Journal of Agronomy, 2012, Article ID: 524075. http://dx.doi.org/10.1155/2012/524075

[45] Montenegro, G., Pereira, K.S. and Melo, L. (2014) The Brazilian Way to Consume Açaí: Do Guaraná Extract and Sugar Concentrations Influence on Acceptance? Journal of Food Research, 3, 39-45. http://dx.doi.org/doi:10.5539/jfr.v3n1p39

[46] NEPA-UNICAMP (2011) Brazilian Table of Composition of Foods (Tabela Brasileira de Composição de Alimentos). 4th Edition, NEPA-UNICAMP, Campinas, $161 \mathrm{p}$.

[47] Darnet, S.H., Da Silva, L.H.M., Rodrigues, A.M.C. and Lins, R.T. (2011) Nutritional Composition, Fatty Acid and Tocopherol Contents of Buriti (Mauritia flexuosa) and Patawa (Oenocarpus bataua) Fruit Pulp from the Amazon Region. Food Science and Technology, 31, 488-491. http://dx.doi.org/10.1590/S0101-20612011000200032

[48] Rufino, M.S.M., Pérez-Jiménez, J., Arranz, S., Alves, R.E., De Brito, E.S., Oliveira, M.S.P. and Saura-Calixto, F. (2011) Açaí (Euterpe oleraceae) "BRS Pará": A Tropical Fruit Source of Antioxidant Dietary Fiber and High Antioxidant Capacity Oil. Food Research International, 44, 2100-2106. http://dx.doi.org/doi:10.1016/j.foodres.2010.09.011

[49] Tonon, R.V., Brabet, C. and Hubinger, M.D. (2010) Anthocyanin Stability and Antioxidant Activity of Spray-Dried Açai (Euterpe oleracea Mart.) Juice Produced with Different Carrier Agents. Food Research International, 43, 907914. http://dx.doi.org/doi:10.1016/j.foodres.2009.12.013

[50] Woodroof, J.G. (1994) Nuts as a Source of Edible Oil. In: Kamel, B.S. and Kakuda, Y., Eds., Technological Advances in Improved and Alternative Sources of Lipids, Springer US, New York, 150-176. http://dx.doi.org/10.1007/978-1-4615-2109-9_6

[51] Baquião, A.C., Zorzete, P., Reis, T.A., Assunção, E., Vergueiro, S. and Correa, B. (2012) Mycoflora and Mycotoxins in Field Samples of Brazil Nuts. Food Control, 28, 224-229. http://dx.doi.org/10.1016/j.foodcont.2012.05.004

[52] Rayman, M.P. (2012) Selenium and Human Health. The Lancet, 379, 1256-1268. http://dx.doi.org/10.1016/S0140-6736(11)61452-9

[53] De Cristo-Araújo, M., Maciel dos Reis, V., Picanço Rodrigues, D. and Clement, C.R. (2013) Domestication of Peach Palm in Southwestern Amazonia. Tipití: Journal of the Society for the Anthropology of Lowland South America, 11, 74-80.

[54] Vargas-Isla, R., Yuyama, L.K.O, Aguiar, J.P.L. and Ishikawa, N.K. (2013) Production of Panus strigellus Spawn Using the Internal Sheath of Peach Palm (Bactris gasipaes) as a Substrate. Interciencia, 38, 733-736.

[55] Da Silva, J.B.F. and Clement, C.R. (2005) Wild Pejibaye (Bactris gasipaes Kunth var. chichagui) in Southeastern Amazonia. Acta Botanica Brasilica, 19, 281-284. http://dx.doi.org/10.1590/S0102-33062005000200010

[56] Azizi, M.H., Andrade, J.S., Lemos, J.S., Souza, S.J., De Souza, R.S. and Hadian, Z. (2012) Quality of Wheat Bread Incorporated with Different Levels of Peach Palm Flour (Bactris gasipaes Kunth). Journal of Tropical Agriculture and Food Science, 40, 13-22.

[57] Leitchik, V.M. and Shelov, S.D. (2003) Some Basic Concepts of Terminology: Traditions and Innovations. Journal of the International Institute for Terminology Research, 14, 86-101.

[58] Bonnin, E. and Lahaye, M. (2013) Contribution of Cell Wall-Modifying Enzymes to the Texture of Fleshy Fruits. The Example of Apple. Journal of the Serbian Chemical Society, 78, 417-427. http://dx.doi.org/10.2298/JSC121123004B 
[59] Costa, F., Costa, G., Sansavini, S., Soglio, V., Gianfranceschi, L., Schouten, H.J., Alba, R. and Giovannoni, J. (2009). Heterologous Comparative Genomics to Identify Candidate Genes Impacting Fruit Quality in Apple (Malus x Domestica Borkh.). Acta Horticulturae, 814, 517-522.

[60] Akter, M.S., Oh, S., Eun, J.B. and Ahmed, M. (2011) Nutritional Compositions and Health Promoting Phytochemicals of Camu-Camu (Myrciaria dubia) Fruit: A Review. Food Research International, 44, 1728-1732. http://dx.doi.org/10.1016/j.foodres.2011.03.045

[61] Revilla, J. (2001) Plants of the Amazonia: Economic and Sustainable Opportunities (Plantas da Amazônia: Oportunidades Econômicas e Sustentáveis). 2nd Edition, Programa de Desenvolvimento Empresarial e Tecnológico, Manaus, 405 p.

[62] Pavan, R., Jain, S. and Kumar, A. (2012) Properties and Therapeutic Application of Bromelain: A Review. Biotechnology Research International, 2012, Article ID: 976203. http://dx.doi.org/10.1155/2012/976203

[63] Finnegana, E., Mahajanb, P.V., O’Connella, M., Francisa, G.A. and O’Beirnea, D. (2013) Modelling Respiration in Fresh-Cut Pineapple and Prediction of Gas Permeability Needs for Optimal Modified Atmosphere Packaging. Postharvest Biology and Technology, 79, 47-53. http://dx.doi.org/10.1016/j.postharvbio.2012.12.015

[64] Hornung-Leoni, C.T. (2011). Bromeliads: Traditional Plant Food in Latin America since Prehispanic Times. Polibotánica, 32, 219-229.

[65] Lim, T.K. (2012) Myrciaria dubia. In: Lim, T.K., Ed., Edible Medicinal and Non-Medicinal Plants, Springer Netherlands, Dordrecht, 631-638. http://dx.doi.org/10.1007/978-94-007-2534-8 86

[66] Andrade, J.S., Coelho, E.G., Oliveira, A.P. and Silva Filho, D.F. (2010) Postharvest Conservation of Cubiu (Solanum sessiliflorum Dunal) Fruits in Response to Passive Modified Atmosphere Associated with Refrigeration. Acta Horticulturae, 864, 439-444.

[67] Kandel, E.R., Schwartz, J.H. and Jessel, T.M. (2000) Principles of Neural Science. 4th Edition, McGraw-Hill, New York, 1414 p.

[68] Law, S.V., Abu Bakar, F., Mat Hashim, D. and Abdul Hamid, A. (2011) Popular Fermented Foods and Beverages in Southeast Asia. International Food Research Journal, 18, 474-483.

[69] Potter, N.N. and Hotchkiss, J.H. (1998) Food Science. 5th Edition, Aspen, Maryland, 608 p.

[70] Schwartz, M.W., Woods, S.C., Porte Jr., D., Seeley, R.J. and Baskin, D.G. (2000) Central Nervous System Control of Food Intake. Nature, 404, 661-671.

[71] Blundell, J.E. and Tremblay, A. (1995) Appetite Control and Energy (Fuel) Balance. Nutrition Research Reviews, 8, 225-242. http://dx.doi.org/10.1079/NRR19950014

[72] Scheurink, A.J.W., Ammar, A.A., Benthem, B., Van Dijk, G. and Södersten, P.A.T. (1999) Exercise and the Regulation of Energy Intake. International Journal of Obesity, 23, S1-S6. http://dx.doi.org/10.1038/sj.ijo.0800876

[73] Castañeda, T.R., Jürgens, H., Wiedmer, P., Pfluger, P., Diano, S., Horvath, T.L., Tang-Christensen, M. and Tscho, M.H. (2005) Obesity and the Neuroendocrine Control of Energy Homeostasis: The Role of Spontaneous Locomotor Activity. The Journal of Nutrition, 135, 1314-1319.

[74] Hawkins, A. and Olszewski, J. (1957) Glia/Nerve Cell Index for Cortex of the Whale. Science, 126, 76-77. http://dx.doi.org/10.1126/science.126.3263.76

[75] Andrade Jr., M.C. (2002) Evolutionary Aspects of Hormones (Aspectos Evolutivos dos Hormônios). Arquivos Brasileiros de Endocrinologia \& Metabologia, 46, 291-298. http://dx.doi.org/10.1590/S0004-27302002000300013

[76] Levin, B.E. and Strack, A.M. (2008) Diet-Induced Obesity in Animal Models and What They Tell Us about Human Obesity. In: Harvey, J. and Withers, D.J., Eds., Neurobiology of Obesity, Cambridge University Press, Cambridge, 164-195. http://dx.doi.org/10.1017/CBO9780511541643.007

[77] Astrup, A. and Finer, N. (2000) Redefining Type 2 Diabetes: “Diabesity” or “Obesity Dependent Diabetes Mellitus”? Obesity Reviews, 1, 57-59. http://dx.doi.org/10.1046/j.1467-789x.2000.00013.x

[78] Zimmet, P., Albert, K.G.M.M. and Shaw, J. (2001) Global and Societal Implications of the Diabetes Epidemic. Nature, 414, 782-787. http://dx.doi.org/10.1038/414782a

[79] Misra, A. and Khurana, L. (2008) Obesity and the Metabolic Syndrome in Developing Countries. The Journal of Clinical Endocrinology \& Metabolism, 93, S9-S30. http://dx.doi.org/10.1210/jc.2008-1595

[80] Esparza-Romero, J., Valencia, M.E., Martinez, M.E., Ravussin, E., Schulz, L.O. and Bennett, P.H. (2010) Differences in Insulin Resistance in Mexican and US Pima Indians with Normal Glucose Tolerance. The Journal of Clinical Endocrinology and Metabolism, 95, E358-E362. http://dx.doi.org/10.1210/jc.2010-0297

[81] Wing, R.R., Goldstein, M.G., Acton, K.J., Birch, L.L., Jakicic, J.M., Sallis Jr., J.F., Smith-West, D., Jeffery, R.W. and Surwit, R.S. (2001) Lifestyle Changes Related to Obesity, Eating Behavior, and Physical Activity. Diabetes Care, 24, 117-123. http://dx.doi.org/10.2337/diacare.24.1.117 
[82] Booth, F.W., Chakravarthy, M.V. and Spangenburg, E.E. (2002) Exercise and Gene Expression: Physiological Regulation of the Human Genome through Physical Activity. Journal of Physiology, 543, 399-411. http://dx.doi.org/10.1113/jphysiol.2002.019265

[83] Lindgärdea, F., Widénb, I., Gebbb, M. and Ahrénc, B. (2004) Traditional versus Agricultural Lifestyle among Shuar Women of the Ecuadorian Amazon: Effects on Leptin Levels. Metabolism: Clinical and Experimental, 53, 1355-1358. http://dx.doi.org/10.1016/j.metabol.2004.04.012

[84] Mussali-Galante, P., Tovar-Sánchez, E., Valverde, M. and Rojas, E. (2014) Genetic Structure and Diversity of Animal Populations Exposed to Metal Pollution. Reviews of Environmental Contamination and Toxicology, 227, 79-106. http://dx.doi.org/10.1007/978-3-319-01327-5_3

[85] Hall, J.A., Dominy, J.E., Lee, Y. and Puigserver, P. (2013) The Sirtuin Family’s Role in Aging and Age-Associated Pathologies. The Journal of Clinical Investigation, 123, 973-979. http://dx.doi.org/10.1172/JCI64094

[86] Kitada, M. and Koya, D. (2013) SIRT1 in Type 2 Diabetes: Mechanisms and Therapeutic Potential. Diabetes \& Metabolism Journal, 37, 315-325. http://dx.doi.org/10.4093/dmj.2013.37.5.315

[87] Martins, I.J. (2013) Increased Risk for Obesity and Diabetes with Neurodegeneration in Developing Countries. Journal of Molecular and Genetic Medicine, S1, 001. http://dx.doi.org/10.4172/1747-0862.S1-001

[88] Heuer, H. and Smalla, K. (2012) Plasmids Foster Diversification and Adaptation of Bacterial Populations in Soil. FEMS Microbiology Reviews, 36, 1083-1104. http://dx.doi.org/10.1111/j.1574-6976.2012.00337.x

[89] Purushotham, A., Xu, Q. and Li, X. (2012) Systemic SIRT1 Insufficiency Results in Disruption of Energy Homeostasis and Steroid Hormone Metabolism upon High-Fat-Diet Feeding. The FASEB Journal, 26, 656-667. http://dx.doi.org/10.1096/fj.11-195172

[90] Dorts, J., Kestemont, P., Marchand, P.A., D’Hollander, W., Thézenas, M.L., Raes, M. and Silvestre, F. (2011) Ecotoxicoproteomics in Gills of the Sentinel Fish Species, Cottus gobio, Exposed to Perfluorooctane Sulfonate (PFOS). Aquatic Toxicology, 103, 1-8. http://dx.doi.org/10.1016/j.aquatox.2011.01.015

[91] Sen, S. and Simmons, R.A. (2010) Maternal Antioxidant Supplementation Prevents Adiposity in the Offspring of Western Diet-Fed Rats. Diabetes, 59, 3058-3065. http://dx.doi.org/10.2337/db10-0301

[92] Streletskaya, N.A., Rusmevichientong, P., Amatyakul, W. and Kaiser, H.M. (2014) Taxes, Subsidies, and Advertising Efficacy in Changing Eating Behavior: An Experimental Study. Applied Economic Perspectives and Policy, 36, 146-174. http://dx.doi.org/10.1093/aepp/ppt032

[93] Quesada, S., Azofeifa, G., Jatunov, S., Jiménez, G., Navarro, L. and Gómez, G. (2011) Carotenoids Composition, Antioxidant Activity and Glycemic Index of Two Varieties of Bactris gasipaes. Emirates Journal of Food and Agriculture, 23, 482-489.

[94] Anil, K.M. and Singh, N.N. (2011) Diabetes: A Pragmatic Therapy with a Goal to Prevent End Stage Kidney Disease and Dialysis. Open Journal of Internal Medicine, 1, 80-92. http://dx.doi.org/10.4236/ojim.2011.13017

[95] López, A. and Seligman, H.K. (2012) Clinical Management of Food-Insecure Individuals with Diabetes. Diabetes Spectrum, 25, 14-18. http://dx.doi.org/10.2337/diaspect.25.1.14

[96] Vuholm, S., Jakobsen, L.M.A., Sørensen, K.V., Kehlet, U., Raben, A. and Kristensen, M. (2014) Appetite and Food Intake after Consumption of Sausages with 10\% Fat and Added Wheat or Rye Bran. Appetite, 73, 205-211. http://dx.doi.org/10.1016/j.appet.2013.09.028

[97] Argote, F.E., Vargas, D.P. and Villada, H.S. (2013) Market Research on the Degree of Acceptance of Cocona Jam in Sibundoy, Putumayo (Investigación de Mercado sobre el Grado de Aceptación de Mermelada de Cocona en Sibundoy, Putumayo). Revista Guillermo de Ockham, 11, 197-206.

[98] Pardo, M.A. (2004) Solanum sessiliflorum Dunal Effect on Lipid and Glucose Metabolism (Efecto de Solanum sessiliflorum Dunal sobre el Metabolismo Lipídico y de la Glucosa). Ciencia e Investigación, 7, 43-48.

[99] Lim, S.H., Kim, M.Y. and Lee, J. (2014) Apple Pectin, a Dietary Fiber, Ameliorates Myocardial Injury by Inhibiting Apoptosis in a Rat Model of Ischemia/Reperfusion. Nutrition Research and Practice, 8, e12.

[100] Sánchez, D., Muguerza, B., Moulay, L., Hernández, R., Miguel, M. and Aleixandre, A. (2008) Highly Methoxylated Pectin Improves Insulin Resistance and Other Cardiometabolic Risk Factors in Zucker Fatty Rats. Journal of Agricultural and Food Chemistry, 56, 3574-3581. http://dx.doi.org/10.1021/jf703598j

[101] Gardner, D.F., Schwartz, L., Krista, M. and Merimee, T.J. (1984) Dietary Pectin and Glycemic Control in Diabetes. Diabetes Care, 7, 1935-5548. http://dx.doi.org/10.2337/diacare.7.2.143

[102] Brazilian Ministry of Agriculture, Livestock and Food Supply (2010) Manual of Unconventional Crops (Manual de Hortaliças Não-Convencionais). Mapa/ACS, Brasília, 92 p.

[103] Belitz, H.D., Grosch, W. and Schieberle, P. (2009) Food Chemistry. 4th Edition, Springer-Verlag, Berlin, 1070 p.

[104] Clement, C.R., Weber, J.C., Van Leeuwen, J., Domian, C.A., Cole, D.M., Lopez, L.A.A. and Argüello, H. (2004) Why 
Extensive Research and Development Did Not Promote Use of Peach Palm Fruit in Latin America. Agroforestry Systems, 61, 195-206. http://dx.doi.org/10.1023/B:AGFO.0000028999.84655.17

[105] Jäger, M. and Padulosi, S. (2012) Reflections on Market-Based Strategies for Enhancing the Use of Agrobiodiversity. In: Padulosi, S., Bergamini, N. and Lawrence, T., Eds., On Farm Conservation of Neglected and Underutilized Species: Status, Trends and Novel Approaches to Cope with Climate Change. Proceedings of an International Conference, Frankfurt, 14-16 June 2011, 241-248.

[106] Farré, M., Picó, Y. and Barceló, D. (2013) Direct Peel Monitoring of Xenobiotics in Fruit by Direct Analysis in Real Time Coupled to a Linear Quadrupole Ion Trap-Orbitrap Mass Spectrometer. Analytical Chemistry, 85, 2638-2644. http://dx.doi.org/10.1021/ac3026702

[107] Wen, H., Yang, H., An, Y.J., Kim, J.M., Lee, D.H., Jin, X., Park, S., Min, K.J. and Park, S. (2013) Enhanced Phase II Detoxification Contributes to Beneficial Effects of Dietary Restriction as Revealed by Multi-Platform Metabolomics Studies. Molecular \& Cellular Proteomics, 12, 575-586. http://dx.doi.org/10.1074/mcp.M112.021352

[108] Shetty, K., Clydesdale, F.M. and Vattem, D.A. (2006) Clonal Screening and Sprout Based Bioprocessing of Phenolic Phytochemicals for Functional Foods. In: Shetty, K., Paliyath, G., Pometto, A. and Levin, R.E., Eds., Food Biotechnology, CRC Press, Boca Raton, 1-23. http://dx.doi.org/10.1201/9781420027976.ch2.02

[109] Linnewiel, K., Ernst, H., Caris-Veyrat, C., Ben-Dor, A., Kampf, A., Salman, H., Danilenko, M., Levy, J. and Sharoni, Y. (2009) Structure Activity Relationship of Carotenoid Derivatives in Activation of the Electrophile/Antioxidant Response Element Transcription System. Free Radical Biology \& Medicine, 47, 659-667. http://dx.doi.org/10.1016/j.freeradbiomed.2009.06.008

[110] Omaye, S.T. (2004) Food and Nutritional Toxicology. CRC Press, Boca Raton. http://dx.doi.org/10.1201/9780203485309.fmatt

[111] Lynch, A.M., Sasaki, J.C., Elespuru, R., Jacobson-Kram, D., Thybaud, V., Boeck, M.D., Aardema, M.J., Aubrecht, J., Benz, R.D., Dertinger, S.D., Douglas, G.R., White, P.A., Escobar, P.A., Fornace Jr., A., Honma, M., Naven, R.T., Schiestl, R.H., Walmsley, R.M., Yamamura, E., Benthem, J. and Kim, J.H. (2011) New and Emerging Technologies for Genetic Toxicity Testing. Environmental and Molecular Mutagenesis, 52, 205-223. http://dx.doi.org/10.1002/em.20614

[112] Ribeiro, J.C. (2010) Evaluation of the Mutagenic and Antimutagenic Potential of Açaí Pulp (Euterpe oleracea Mart.) and Buriti Oil (Mauritia flexuosa) in Vivo (Avaliação do Potencial Mutagênico e Antimutagênico da Polpa de Açaí (Euterpe oleracea Mart.) e do Óleo de Buriti (Mauritia flexuosa) in Vivo. Thesis, Faculdade de Ciências Farmacêuticas de Ribeirão Preto, Universidade de São Paulo, Ribeirão Preto.

[113] Hernandes, L.C. (2013) Cytotoxicity, Genotoxicity and Antigenotoxicity Evaluations and Gene Expression of iNOS and COX-2 in Rats Treated with the Fruit Pulp of Solanum sessiliflorum Dunal (Avaliação da Citotoxicidade, Genotoxicidade, Antigenotoxicidade e Expressão dos Genes iNOS e COX-2 em Ratos Tratados com a Polpa do Fruto de Solanum sessiliflorum Dunal). Thesis, Faculdade de Ciências Farmacêuticas de Ribeirão Preto, Universidade de São Paulo, Ribeirão Preto.

[114] Souza Filho, O.C., Sagrillo, M.R., Garcia, L.F.M., Machado, A.K., Cadoná, F., Ribeiro, E.E., Duarte, M.M.M.F., Morel, A.F. and Cruz, I.B.M. (2013) The in Vitro Genotoxic Effect of Tucuma (Astrocaryum aculeatum), an Amazonian Fruit Rich in Carotenoids. Journal of Medicinal Food, 16, 1013-1021. http://dx.doi.org/10.1089/jmf.2012.0287 
Scientific Research Publishing (SCIRP) is one of the largest Open Access journal publishers. It is currently publishing more than 200 open access, online, peer-reviewed journals covering a wide range of academic disciplines. SCIRP serves the worldwide academic communities and contributes to the progress and application of science with its publication.

Other selected journals from SCIRP are listed as below. Submit your manuscript to us via either submit@scirp.org or Online Submission Portal.
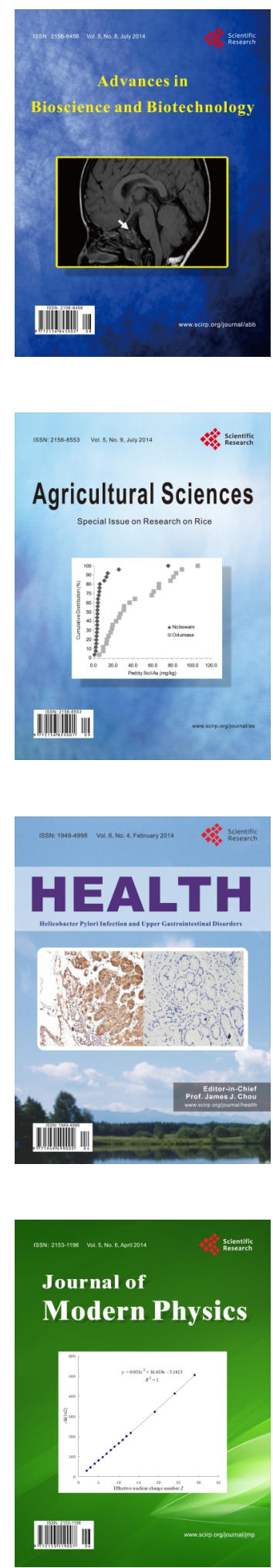
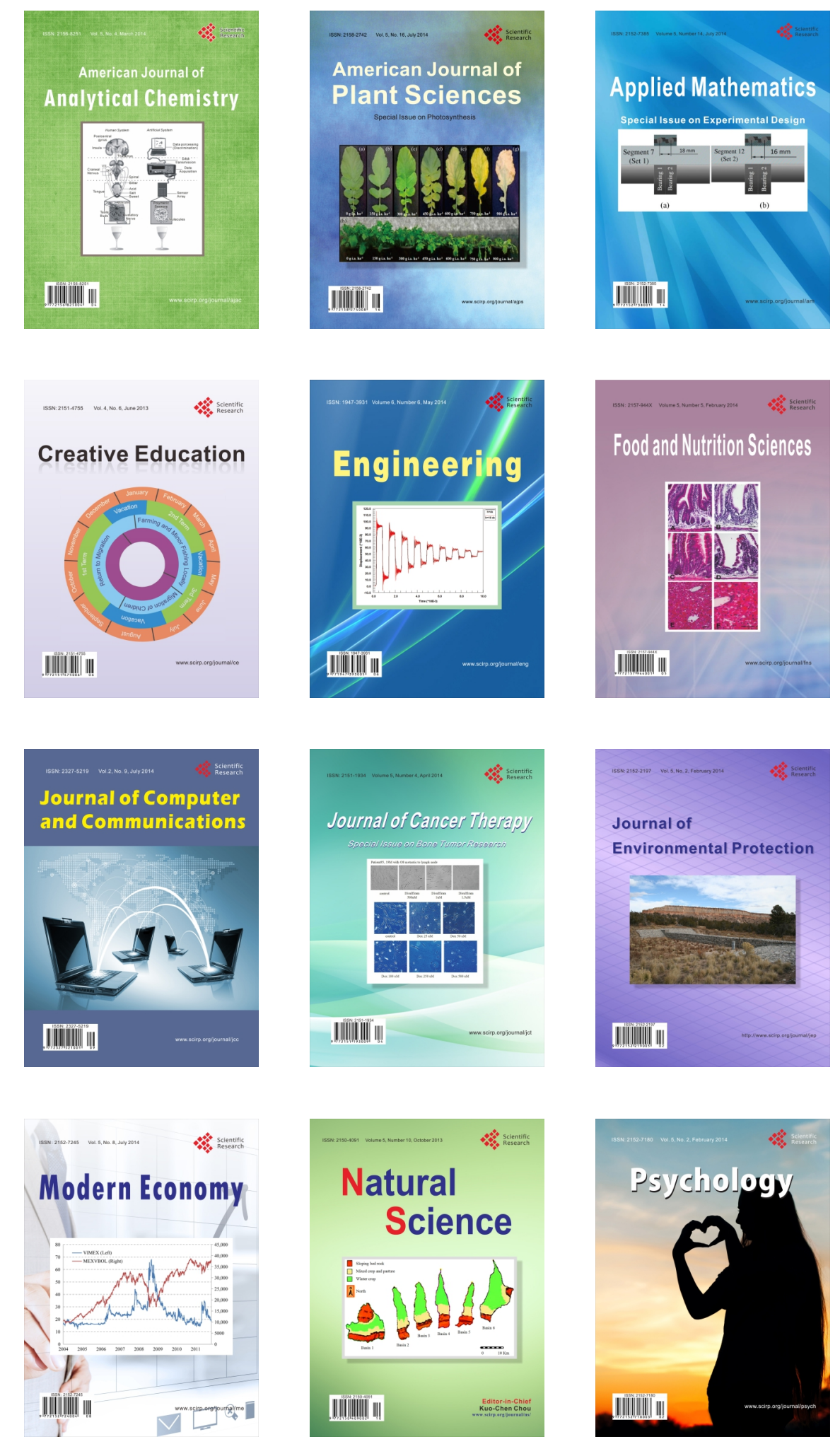